\title{
Correlation and Path Coefficient Analysis for Yield and Yield Attributes in Cluster Bean [Cyamopsis tetragonoloba (L.) Taub.] Genotypes
}

\author{
T. Yeswanth Mahidar Gowd ${ }^{1}$, P. Syam Sundar Reddy ${ }^{*}$, B. Tanuja Priya ${ }^{2}$, \\ Y. Deepthi Kiran ${ }^{3}$ and A. Ramanjaneya Reddy ${ }^{4}$ \\ ${ }^{1}$ Department of Vegetable Science, ${ }^{2}$ Department of Fruit Science, ${ }^{3}$ Department of Agronomy, \\ ${ }^{4}$ Department of Soil Science, College of Horticulture, Anantharajupeta, \\ Andhra Pradesh, India \\ *Corresponding author
}

\section{A B S T R A C T}

\begin{tabular}{|l|}
\hline Ke y w o r d s \\
Cluster bean, \\
$\begin{array}{l}\text { Correlation, Path } \\
\text { coefficient analysis, } \\
\text { Vegetative } \\
\text { characters, Pod } \\
\text { yield }\end{array}$ \\
\hline Article Info \\
\hline $\begin{array}{l}\text { Accepted: } \\
\text { 04 August 2020 } \\
\text { Available Online: } \\
\text { 10 September 2020 }\end{array}$ \\
\hline
\end{tabular}

Forty five cluster bean genotypes (Cyamopsis tetragonoloba (L.) Taub) were evaluated to find out the correlation and path analysis for vegetable pod yield and yield attributes during kharif 2018 at College of Horticulture, Anantharajupeta, Andhra Pradesh. Character association of the yield attributing traits revealed that fresh pod yield per plant had highly significant and positive association with pod length, number of pods per plant, number of pods per cluster, number of pod clusters per plant and number of branches per plant at maturity. Direct selection based on these traits could result in simultaneous improvement of afore said traits and marketable pod yield in cluster bean. From path analysis, it can be inferred that very high positive direct effect on fresh pod yield per plant was exerted by number of clusters per pod at genotypic levels while pod length, number of pod clusters per plant, number of pods per plant and number of clusters per plant exerted a positive and high direct effect on fresh pod yield per plant at both genotypic and phenotypic levels. High negative direct effect on fresh pod yield per plant was exerted by days to first flowering and days to $50 \%$ flowering. High direct effect of these traits appeared to be the main factor for their strong association with pod yield per plant. Hence direct selection for these traits would be highly effective in improving the pod yield per plant.

\section{Introduction}

Cluster bean $(2 \mathrm{n}=2 \mathrm{x}=14)$ commonly known as guar, is an important self-pollinated leguminous crop belong to family Leguminaceae. Guar is a crop of arid and semi arid tropical areas spread over the North and North Western part of India requiring low inputs and care. Guar is mainly cultivated for food as vegetable, feed and fodder (Pawan kumar et al., 2017). It is cultivated mainly in rainy season as a rainfed crop in arid zones of India and various other parts of the world (Pathak et al., 2009). The crop is mainly grown in the dry habitats of Rajasthan, Haryana, Gujarat and Punjab and to a limited extent in Uttar Pradesh, Madhya Pradesh, Andhra Pradesh, Tamil Nadu, Karnataka and Kerala. 
In spite of the importance of this crop in agricultural production, productivity of this crop is very low in India due to lack of suitable high yielding varieties, rainfed cultivation, improper time of sowing, pests and diseases incidence, inadequate fertilization and improper agronomic practices. Therefore, there is an urgent need to design breeding programmes that can enhance productivity and stabilize the yield.

Yield, being a complex trait, is composed of several components some of which affect the yield directly while, others affect indirectly. Hence knowledge of association between yield and its components is necessary. Correlation studies would provide estimates of degree of association between seed yield and its components and also among the components. While path co-efficient analysis further elucidates the intrinsic nature of association of component traits by determining direct or indirect contribution of these traits to yield.

\section{Materials and Methods}

A field experiment was conducted at Vegetables block, College of Horticulture, Anantharajupeta, YSR Kadapa (Dt), Dr. Y. S. R. Horticultural University, Andhra Pradesh during kharif 2018. Cluster bean germplasm comprising of 45 genotypes (Table 1) (including check varieties Pusa Navbahar and MDU-1) were collected from different geographical regions were evaluated in a randomized complete block design (RCBD) with three replications. Each genotype was sown in double row plot of $4 \mathrm{~m}$ row length. Row to row and plant to plant distances were maintained as $40 \mathrm{~cm}$ and $30 \mathrm{~cm}$, respectively. Uniform recommended package of practices were adopted to raise a good crop. Observations were recorded on five randomly selected plants in each from each replication. The observations on plant height at 30 days $(\mathrm{cm})$, plant height at harvest $(\mathrm{cm})$, number of branches per plant, days to first flowering, days to $50 \%$ flowering, days to pod maturity, pod length $(\mathrm{cm})$, pod thickness $(\mathrm{mm})$, pod width $(\mathrm{mm})$, number of pods per cluster, number of clusters per plant, number of pods per plant, number of seeds per pod, pod yield per plant (g), pod yield (t/ha) 100 seed weight, protein content (\%) and gum content $(\%)$.

Genotypic and phenotypic correlation coefficient was calculated by using the method given by Johnson et al., (1955). The genotypic and phenotypic correlation coefficients were used in finding out their direct and indirect contribution towards yield per plot. The path coefficient analysis was carried out by the method suggested by Dewey and Lu (1959) to partition the genotypic correlation coefficients into measures of direct and indirect effects.

\section{Results and Discussion}

Selection based on the detailed knowledge of magnitude and direction of association between yield and its attributes is very important in identifying the key characters, which can be exploited for crop improvement through suitable breeding programme. The estimates of correlation coefficients are presented in Table 2 and 3. In general genotypic correlation coefficients were higher than phenotypic correlation coefficient for all the characters under study.

Number of clusters per plant showed highly significant and positive correlation with number of branches per plant at maturity at both phenotypic and genotypic level. Similar results were reported by Saini et al., (2010) and Girish et al., (2012). This indicates there is a strong association of this trait to the total yield through the number of clusters per plant. Hence, more branches per plant indirectly resulted into higher yield. 
Pod yield per plant exhibited highly significant positive association with pod length, number of pods per plant, number of pods per cluster, number of clusters per plant and number of branches per plant at maturity. These results are in agreement with Anandhi and Oommen (2010), Rai and Dharmatti (2014), Kumar and Ram (2015) and Vir and Singh (2015) for number of pods per plant ; Rai and Dharmatti (2014), Girish et al., (2012), Kastoori et al., (2009), Patil (2014) for number of clusters per plant. Days to pod maturity showed significant negative association with pod yield per plant and these results are in agreement with Patil (2014).

Present results indicate the importance of these traits in selection for marketable pod yield per plant. Direct selection based on these traits would result in simultaneous improvement of afore said traits and yield in cluster bean. Thus, the pod length and number of pods per plant seems to have predominant effect on pod yield per plant. Hence, there is an ample scope in the improvement of yield by selecting a genotype having higher pod length and number of pods per plant since they are highly correlated.

The results on character association indicated significant positive association of yield with pod length, number of clusters per plant, number of pods per plant and pod yield per hectare which indicated that the adequate knowledge of interrelationship between marketable pod yield per plant and its components themselves is useful for selection and simultaneous improvement for these characters (Fig. 1).

Table.1 Source and place of collection used in the study of Cluster bean genotypes

\begin{tabular}{|c|c|c|}
\hline Source & $\begin{array}{l}\text { Number of } \\
\text { genotypes }\end{array}$ & Genotypes \\
\hline $\begin{array}{l}\text { ARS, Durgapur, } \\
\text { Rajasthan }\end{array}$ & 18 & $\begin{array}{l}\text { GP-1,GP-2,GP-3,GP-5,GP-6,GP-7, GP-8,GP-10,GP-11, GP-12,GP- } \\
\text { 13, GP-14,GP-15,GP-16,GP-17,GP-18, GP-19, GP-20. }\end{array}$ \\
\hline $\begin{array}{l}\text { NBPGR, } \\
\text { Jodhpur, } \\
\text { Rajasthan }\end{array}$ & 25 & $\begin{array}{l}\text { IC-113272,IC-113278,IC-113281, IC-113308,IC113377,IC113390, } \\
\text { IC-113393,IC-113394,IC-113396, IC-113499,IC-113506,IC113523, } \\
\text { IC-113568,IC-116569,IC-116608,IC-116619, IC-116626,IC116652, } \\
\text { IC-116660,IC-116705, IC-116779,IC-116825,IC-116925,IC116930, } \\
\text { IC-116932. }\end{array}$ \\
\hline $\begin{array}{l}\text { AAU, Anand, } \\
\text { Gujarat }\end{array}$ & 1 & Pusa Navbahar \\
\hline $\begin{array}{l}\text { TNAU, } \\
\text { Coimbatore, } \\
\text { Tamilnadu }\end{array}$ & 1 & MDU-1 \\
\hline
\end{tabular}


Table.2 Phenotypic correlation matrix for different characters among forty five cluster bean genotypes

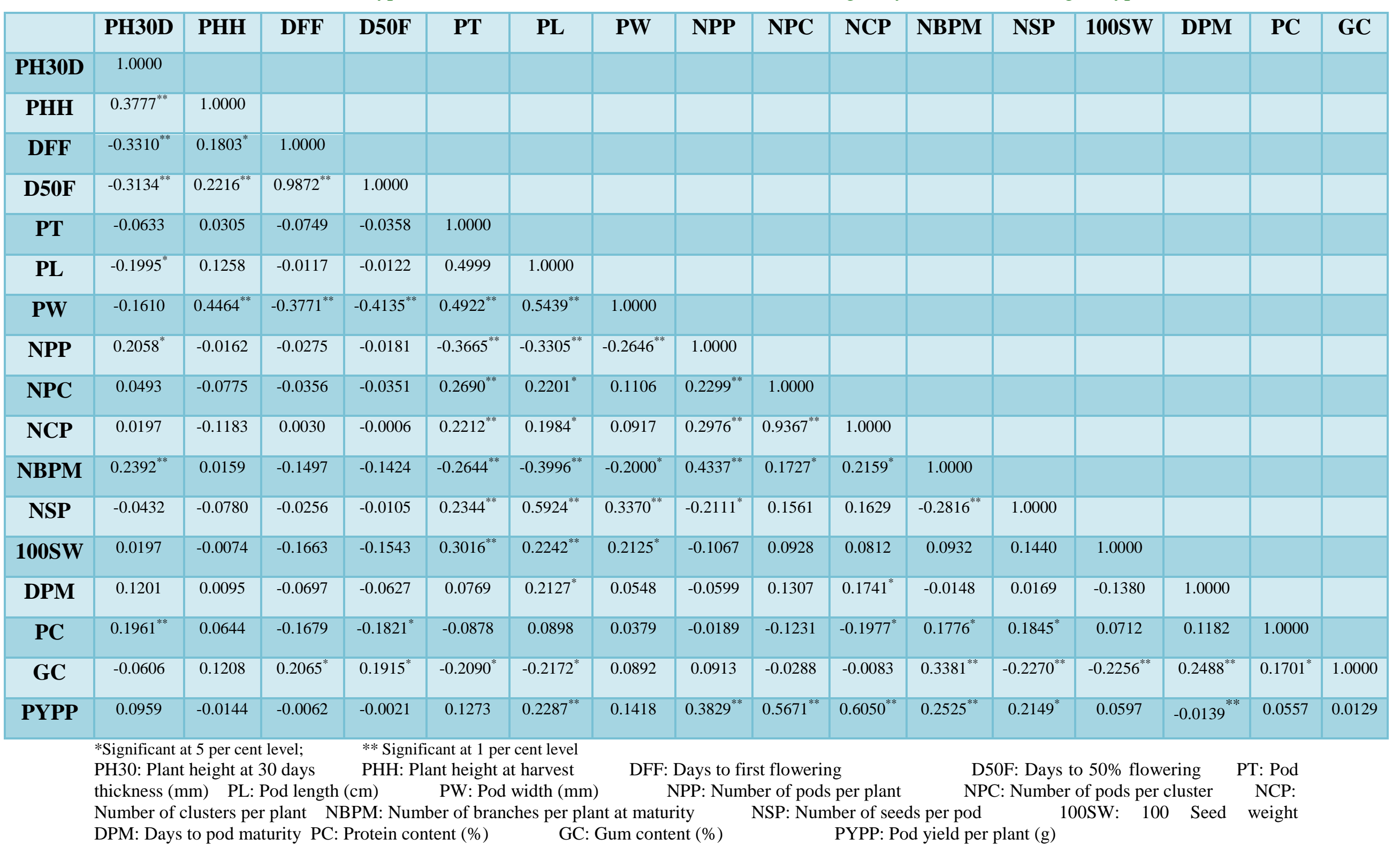


Table.3 Genotypic correlation matrix for different characters among forty five cluster bean genotypes

\begin{tabular}{|c|c|c|c|c|c|c|c|c|c|c|c|c|c|c|c|c|}
\hline & PH30D & PHH & DFF & D50F & PT & PL & $\mathbf{P W}$ & NPP & NPC & NCP & NBPM & I NSP & 100SW & DPM & PC & GC \\
\hline PH30D & 1.0000 & & & & & & & & & & & & & & & \\
\hline PHH & $0.9203^{* *}$ & 1.0000 & & & & & & & & & & & & & & \\
\hline DFF & $-0.6067^{* *}$ & $-0.6775^{* * *}$ & * 1.0000 & & & & & & & & & & & & & \\
\hline D50F & $-0.6065^{* *}$ & $-0.7199^{* * *}$ & ${ }^{*} 0.9837^{* *}$ & 1.0000 & & & & & & & & & & & & \\
\hline PT & -0.0482 & -0.0466 & -0.1547 & -0.1129 & 1.0000 & & & & & & & & & & & \\
\hline PL & $-0.4134^{* *}$ & $-0.2759^{* * *}$ & -0.0257 & -0.0284 & $0.5964^{* *}$ & 1.0000 & & & & & & & & & & \\
\hline PW & $0.3465^{* *}$ & $0.2169^{*}$ & $-0.3645^{* * *}$ & $-0.3309^{* *}$ & $0.1818^{* * *}$ & -0.0547 & 1.0000 & & & & & & & & & \\
\hline NPP & $0.1904^{*}$ & -0.0339 & -0.0735 & -0.0535 & $-0.6956^{* *}$ & $-0.7329^{* * *}$ & $0.2946^{* * *}$ & 1.0000 & & & & & & & & \\
\hline NPC & 0.0761 & -0.1620 & -0.0521 & -0.0551 & $0.2975^{* *}$ & $0.2442^{* *}$ & $0.2893^{* * *}$ & $0.4082^{* * *}$ & 1.0000 & & & & & & & \\
\hline NCP & 0.0219 & $-0.2676^{* *}$ & -0.0139 & -0.0210 & $0.2501^{* *}$ & $0.2277^{* * *}$ & 0.1282 & $0.5080^{* * *}$ & $0.9587^{* * *}$ & 1.0000 & & & & & & \\
\hline NBPM & 0.3200 & $-0.3163^{* *}$ & $-0.3352^{* *}$ & $-0.3573^{* *}$ & ${ }^{*}-0.3225^{* *}$ & ${ }^{*}-0.4604^{* *}$ & $0.2462^{* * *}$ & $0.8295^{* * *}$ & 0.1774 & $0.2222^{* * *}$ & 1.0000 & & & & & \\
\hline NSP & -0.1174 & $-0.1761^{*}$ & -0.0422 & -0.0254 & $0.2709^{* * *}$ & $0.6566^{* * *}$ & 0.0142 & $-0.4273^{* * *}$ & 0.1621 & $0.1685^{*}$ & $-0.3037^{* *}$ & 1.0000 & & & & \\
\hline 100SW & 0.1268 & -0.0434 & $-0.2359^{* *}$ & $-0.2305^{* *}$ & ${ }^{*} 0.3770^{* *}$ & $0.2523^{* *}$ & $-0.5769^{* * *}$ & $-0.3621^{* *}$ & 0.1112 & 0.0887 & 0.1085 & $0.1881^{*}$ & 1.0000 & & & \\
\hline DPM & $0.1830^{*}$ & -0.0173 & -0.1017 & -0.0982 & 0.0630 & $0.2383^{* *}$ & -0.1583 & -0.1332 & 0.1409 & $0.1763^{*}$ & -0.0215 & 0.0180 & -0.1597 & 1.0000 & & \\
\hline PC & 0.2860 & 0.1191 & -0.2052 & $-0.2339^{* *}$ & -0.0987 & 0.0990 & -0.0530 & -0.0332 & -0.1242 & $-0.2026^{*}$ & $0.1826^{* * *}$ & $0.1893^{*}$ & 0.0811 & 0.1214 & 1.0000 & \\
\hline GC & 0.0395 & $-0.7309^{* *}$ & 0.0619 & 0.1446 & $-0.4710^{* *}$ & ${ }^{*}-0.3469^{* * *}$ & -0.1367 & $0.5176^{* * *}$ & -0.0664 & -0.0117 & $0.4206^{* *}$ & $-0.3782^{*}$ & ${ }^{*}-0.3213^{* *}$ & $0.3749 * *$ & $0.2823^{* *}$ & 1.0000 \\
\hline PYPP & -0.0614 & -0.2587 & -0.1186 & -0.1261 & 0.1096 & $0.3054^{* *}$ & 0.2204 & $0.7680^{* *}$ & $0.7115^{* * *}$ & ${ }^{*} 0.7865^{* * *}$ & $0.2953^{* * *}$ & $0.2687^{* *}$ & 0.0507 & $-0.0092^{* *}$ & 0.0717 & -0.1278 \\
\hline
\end{tabular}

*Significant at 5 per cent level; $\quad * *$ Significant at 1 per cent level

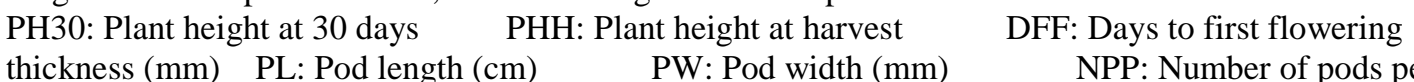

Number of clusters per plant NBPM: Number of branches per plant at maturity

DPM: Days to pod maturity PC: Protein content (\%) GC: Gum content (\%)
D50F: Days to $50 \%$ flowering NPC: Number of pods per cluster 
Table.4 Phenotypic path coefficient analysis for different characters among forty five cluster bean genotypes

\begin{tabular}{|c|c|c|c|c|c|c|c|c|c|c|c|c|c|c|c|c|c|}
\hline & PH30 D & РНH & DFF & D50F & PT & PL & PW & NPP & NPC & NCP & NBPM & NSP & 100SW & DPM & PC & GC & PYPP \\
\hline PH30D & 0.0493 & 0.0186 & -0.0163 & -0.0155 & -0.0031 & -0.0098 & 0.0053 & 0.0102 & 0.0024 & 0.0010 & 0.0118 & -0.0021 & 0.0045 & 0.0059 & 0.0097 & -0.0030 & 0.0959 \\
\hline PHH & 0.0164 & 0.0434 & 0.0078 & 0.0096 & 0.0013 & -0.0055 & 0.0035 & -0.0007 & -0.0034 & -0.0051 & 0.0007 & -0.0034 & -0.0003 & 0.0004 & 0.0028 & 0.0052 & -0.0144 \\
\hline DFF & -0.0111 & 0.0060 & -0.0335 & 0.0330 & -0.0025 & -0.0004 & -0.0022 & -0.0009 & -0.0012 & 0.0001 & -0.0050 & -0.0009 & -0.0056 & -0.0023 & -0.0056 & 0.0069 & -0.0062 \\
\hline D50F & -0.0003 & 0.0002 & 0.0010 & -0.0010 & 0.0000 & 0.0000 & -0.0001 & 0.0000 & 0.0000 & 0.0000 & -0.0001 & 0.0000 & -0.0002 & -0.0001 & -0.0002 & 0.0002 & -0.0021 \\
\hline PT & -0.0034 & 0.0016 & -0.0040 & -0.0019 & 0.0537 & 0.0268 & 0.0029 & -0.0197 & 0.0144 & 0.0119 & -0.0142 & 0.0126 & 0.0162 & 0.0041 & -0.0047 & -0.0112 & 0.1273 \\
\hline PL & -0.0549 & -0.0346 & -0.0032 & -0.0033 & 0.1375 & 0.2751 & -0.0133 & -0.0909 & 0.0606 & 0.0546 & -0.1099 & 0.1630 & 0.0617 & 0.0585 & 0.0247 & -0.0597 & 0.2287 \\
\hline PW & 0.0098 & 0.0074 & -0.0061 & -0.0047 & 0.0049 & -0.0044 & 0.0912 & 0.0076 & 0.0080 & 0.0032 & 0.0088 & -0.0032 & -0.0142 & -0.0021 & -0.0019 & 0.0031 & 0.1418 \\
\hline NPP & 0.0564 & -0.0044 & -0.0075 & -0.0050 & -0.1005 & -0.0906 & 0.0230 & 0.2741 & 0.0630 & 0.0816 & 0.1189 & -0.0578 & -0.0292 & -0.0164 & -0.0052 & 0.0250 & 0.3829 \\
\hline NPC & -0.0052 & 0.0082 & 0.0037 & 0.0037 & -0.0283 & -0.0232 & -0.0092 & -0.0242 & -0.1053 & -0.0986 & -0.0182 & -0.0164 & -0.0098 & -0.0138 & 0.0130 & 0.0030 & 0.5671 \\
\hline NCP & 0.0113 & -0.0678 & 0.0017 & -0.0003 & 0.1269 & 0.1138 & 0.0204 & 0.1707 & 0.5373 & 0.5736 & 0.1238 & 0.0934 & 0.0466 & 0.0999 & -0.1134 & -0.0047 & 0.6050 \\
\hline NBPM & 0.0302 & 0.0020 & -0.0189 & -0.0180 & -0.0334 & -0.0504 & 0.0122 & 0.0547 & 0.0218 & 0.0272 & 0.1261 & -0.0355 & 0.0118 & -0.0019 & 0.0224 & 0.0426 & 0.2525 \\
\hline NSP & -0.0025 & -0.0046 & -0.0015 & -0.0006 & 0.0137 & 0.0346 & -0.0020 & -0.0123 & 0.0091 & 0.0095 & -0.0164 & 0.0583 & 0.0084 & 0.0010 & 0.0108 & -0.0132 & 0.2149 \\
\hline 100SW & -0.0049 & 0.0004 & 0.0090 & 0.0083 & -0.0162 & -0.0121 & 0.0084 & 0.0057 & -0.0050 & -0.0044 & -0.0050 & -0.0078 & -0.0538 & 0.0074 & -0.0038 & 0.0121 & 0.0597 \\
\hline DPM & -0.0176 & -0.0014 & 0.0102 & 0.0092 & -0.0113 & -0.0312 & 0.0034 & 0.0088 & -0.0192 & -0.0255 & 0.0022 & -0.0025 & 0.0202 & -0.1466 & -0.0173 & -0.0365 & 0.0139 \\
\hline PC & 0.0237 & 0.0078 & -0.0203 & -0.0220 & -0.0106 & 0.0108 & -0.0025 & -0.0023 & -0.0149 & -0.0239 & 0.0214 & 0.0223 & 0.0086 & 0.0143 & 0.1207 & 0.0205 & 0.0557 \\
\hline GC & -0.0014 & 0.0027 & 0.0046 & 0.0043 & -0.0047 & -0.0049 & 0.0008 & 0.0021 & -0.0006 & -0.0002 & 0.0076 & -0.0051 & -0.0051 & 0.0056 & 0.0038 & 0.0225 & 0.0129 \\
\hline
\end{tabular}

Residual effect $=0.6892$

PH30: Plant height at 30 days $\quad$ PHH: Plant height at harvest $\quad$ DFF: Days to first flowering $\quad$ D50F: Days to 50\% flowering Pod thickness $(\mathrm{mm}) \quad$ PL: Pod length $(\mathrm{cm}) \quad$ PW: Pod width $(\mathrm{mm}) \quad$ NPP: Number of pods per plant NPC: Number of pods per cluster $\quad$ NCP: Number of clusters per plant NBPM: Number of branches per plant at maturity $\quad$ NSP: Number of seeds per pod $\quad 100 S W$ : $100 \quad$ Seed weight DPM: Days to pod maturity PC: Protein content (\%) GC: Gum content (\%) PYPP: Pod yield per plant $(\mathrm{g})$ 
Table.5 Genotypic path coefficient analysis for different characters among forty five cluster bean genotypes

\begin{tabular}{|c|c|c|c|c|c|c|c|c|c|c|c|c|c|c|c|c|c|}
\hline & PH30D & РНH & DFF & D50F & PT & PL & PW & NPP & NPC & NCP & NBPM & NSP & 100SW & DPM & PC & GC & PYPP \\
\hline PH30D & 0.0482 & 0.0444 & -0.0293 & -0.0292 & -0.0023 & -0.0199 & 0.0167 & 0.0092 & 0.0037 & 0.0011 & 0.0154 & -0.0057 & 0.0061 & 0.0088 & 0.0138 & 0.0019 & -0.0614 \\
\hline РHH & 0.0290 & 0.0315 & -0.0213 & -0.0227 & -0.0015 & -0.0087 & 0.0068 & -0.0011 & -0.0051 & -0.0084 & -0.0100 & -0.0055 & -0.0014 & -0.0005 & 0.0038 & -0.0230 & -0.2587 \\
\hline DFF & 1.0172 & 1.1360 & -1.6767 & -1.6494 & 0.2594 & 0.0430 & 0.6112 & 0.1232 & 0.0873 & 0.0233 & 0.5620 & 0.0708 & 0.3956 & 0.1705 & 0.3440 & 0.1038 & -0.1186 \\
\hline D50F & -0.9041 & -1.0732 & 1.4664 & -1.4907 & -0.1683 & -0.0424 & -0.4934 & -0.0798 & -0.0822 & -0.0313 & -0.5326 & -0.0378 & -0.3436 & -0.1464 & -0.3487 & -0.2156 & -0.1261 \\
\hline PT & 0.0215 & 0.0207 & 0.0689 & 0.0503 & -0.4451 & -0.2655 & -0.0809 & 0.3096 & -0.1324 & -0.1113 & 0.1435 & -0.1206 & -0.1678 & -0.0280 & 0.0439 & 0.2096 & 0.1096 \\
\hline PL & -0.2298 & -0.1533 & -0.0143 & -0.0158 & 0.3315 & 0.5559 & -0.0304 & -0.4074 & 0.1357 & 0.1266 & -0.2559 & 0.3650 & 0.1403 & 0.1325 & 0.0550 & -0.1929 & 0.3054 \\
\hline PW & -0.0756 & -0.0474 & 0.0796 & 0.0723 & -0.0397 & 0.0120 & -0.2183 & -0.0643 & -0.0631 & -0.0280 & -0.0537 & 0.0031 & 0.1259 & 0.0346 & 0.0116 & 0.0298 & 0.2204 \\
\hline NPP & -0.0883 & 0.0157 & 0.0341 & 0.0248 & 0.3226 & 0.3399 & -0.1366 & 0.4637 & -0.1893 & 0.2356 & -0.3847 & 0.1982 & 0.1679 & 0.0618 & 0.0154 & -0.2400 & 0.7680 \\
\hline NPC & -0.0678 & 0.1445 & 0.0465 & 0.0492 & -0.2654 & -0.2178 & -0.2580 & -0.3641 & -0.8921 & 0.8553 & -0.1583 & -0.1446 & -0.0992 & -0.1257 & 0.1108 & 0.0592 & 0.7115 \\
\hline NCP & 0.0448 & -0.5482 & -0.0285 & -0.0430 & 0.5122 & 0.4663 & 0.2626 & 1.0404 & 1.9636 & 2.0482 & 0.4552 & 0.3452 & 0.1816 & 0.3612 & -0.4149 & -0.0240 & 0.7865 \\
\hline NBPM & 0.1656 & -0.1637 & -0.1735 & -0.1849 & -0.1669 & -0.2383 & 0.1274 & 0.4293 & 0.0918 & 0.1150 & 0.5175 & -0.1572 & 0.0562 & -0.0111 & 0.0945 & 0.2177 & 0.2953 \\
\hline NSP & 0.0361 & 0.0541 & 0.0130 & 0.0078 & -0.0833 & -0.2019 & 0.0044 & 0.1314 & -0.0499 & -0.0518 & 0.0934 & -0.3075 & -0.0578 & -0.0055 & -0.0582 & 0.1163 & 0.2687 \\
\hline 100SW & -0.0696 & 0.0238 & 0.1294 & 0.1265 & -0.2068 & -0.1384 & 0.3164 & 0.1986 & -0.0610 & -0.0486 & -0.0595 & -0.1032 & -0.5485 & 0.0876 & -0.0445 & 0.1762 & 0.0507 \\
\hline DPM & -0.0865 & 0.0082 & 0.0481 & 0.0464 & -0.0298 & -0.1126 & 0.0748 & 0.0630 & -0.0666 & -0.0833 & 0.0102 & -0.0085 & 0.0755 & -0.4726 & -0.0574 & -0.1772 & 0.0092 \\
\hline PC & 0.1089 & 0.0454 & -0.0782 & -0.0891 & -0.0376 & 0.0377 & -0.0202 & -0.0126 & -0.0473 & -0.0772 & 0.0695 & 0.0721 & 0.0309 & 0.0462 & 0.3809 & 0.1075 & 0.0717 \\
\hline GC & -0.0109 & 0.2027 & 0.0172 & 0.0401 & 0.1306 & 0.0962 & 0.0379 & -0.1435 & 0.0184 & 0.0032 & -0.1167 & 0.1049 & 0.0891 & -0.1040 & -0.0783 & -0.2773 & -0.1278 \\
\hline
\end{tabular}

Residual effect $=0.4545$

PH30: Plant height at 30 days $\quad$ PHH: Plant height at harvest

\section{DFF: Days to first flowering} NPP: Number of pods per plant

D50F: Days to $50 \%$ flowering NPC: Number of pods per cluster

PT: Pod thickness $(\mathrm{mm}) \quad$ PL: Pod length $(\mathrm{cm}) \quad$ PW: Pod width (mm)

Number of clusters per plant NBPM: Number of branches per plant at maturity

DPM: Days to pod maturity PC: Protein content (\%)
NSP: Number of seeds per pod

100SW: 100 Seed weight PYPP: Pod yield per plant $(\mathrm{g})$ 
Fig.1 Genotypic and phenotypic path diagram representing direct and indirect effects for pod yield per plant of forty five cluster bean genotypes

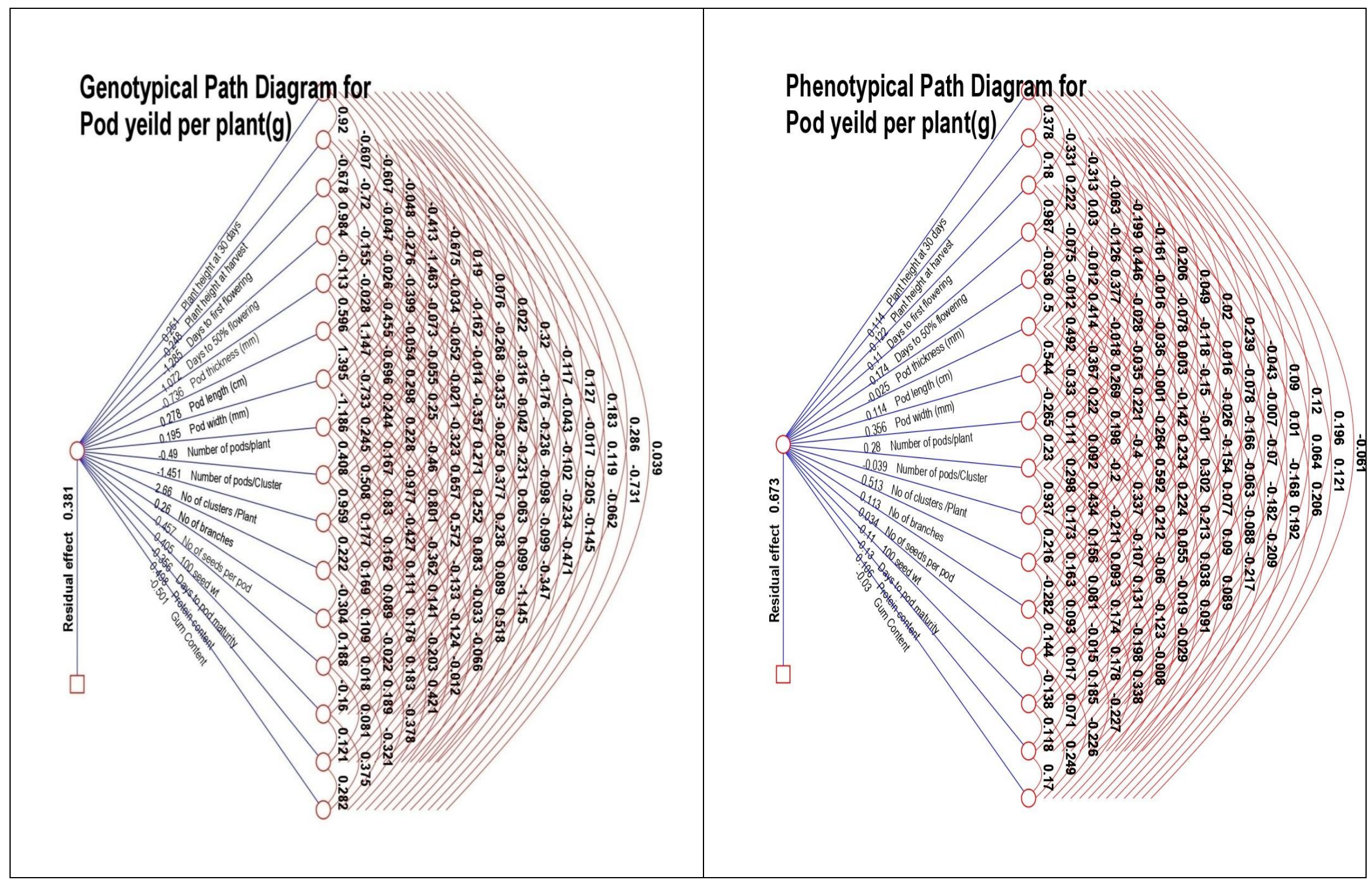


Path analysis was carried out at phenotypic and genotypic level considering pod yield per plant as dependent variable and its attributes as independent variables. Upon the assessment of apparent relationship between yield and yield components, it was necessary to partition the direct and indirect effects of each character on yield to understand the nature of association at genotypic and phenotypic level. The direct and indirect effects of different characters on yield per plant are presented in the Table 4 and 5.

From path analysis, it can be inferred that pod length, number of clusters per plant, number of pods per plant and number of clusters per plant exerted a high positive direct effect on pod yield per plant at both genotypic and phenotypic levels. The high direct effect of these traits appeared to be the main factor for their strong association with pod yield per plant. Hence, direct selection for these traits would be highly effective in improving the per plant pod yield. These results are in agreement with Kumar (2016) and Lekshmanan and Abdul (2016).

Pod length exhibited a very high positive indirect effect through number of pods per plant and number of seeds per pod on pod yield per plant. As pod length influences pod yield per plant through these characters, indirect selection for pod length via the aforesaid characters may be useful in improving the yield. Genotypic residual effect was found to be enough which indicates that selected traits for genotypes cover the maximum of genetic variation.

Number of clusters per plant exerted a positive indirect effect through number of pods per plant, number of pods per cluster, number of branches per plant at maturity and number of seeds per pod. Therefore, it would be rewarding to stress on number of pods per plant, number of pods per cluster and number of branches per plant at maturity while making selection. Since this trait also showed high correlation and high direct effect on pod yield per plant, one can improve the pod yield per plant by making selection for these characters during yield improvement programme.

The results of the study indicated that the characters with positive correlation have shown high direct effects. Thus, pod length, number of clusters per plant, number of pods per plant, number of branches per plant at maturity and protein content had high direct and correlation values.

In conclusion, the correlation studies, revealed that fresh pod yield per plant had highly significant and positive association with pod length, number of pods per plant, number of pods per cluster, number of clusters per plant and number of branches per plant at maturity. Direct selection based on these traits could result in simultaneous improvement of afore said traits and marketable pod yield in cluster bean.

From path analysis, it can be inferred that very high positive direct effect on fresh pod yield per plant was exerted by number of clusters per pod at genotypic levels while pod length, number of clusters per plant, number of pods per plant and number of clusters per plant exerted a positive and high direct effect on fresh pod yield per plant at both genotypic and phenotypic levels.

High negative direct effect on fresh pod yield per plant was exerted by days to first flowering and days to $50 \%$ flowering. High direct effect of these traits appeared to be the main factor for their strong association with pod yield per plant. Hence direct selection for these traits would be highly effective in improving the pod yield per plant. 


\section{References}

Anandhi K and Oommen, S.K. 2010. Correlation studies in cluster bean. Legume Research. 33(3): 227-28.

Dewey D.R. and Lu, K.H. 1959. A Correlation and path coefficient analysis of components of crested Wheat grass. Agronomy Journal. 51: 515-18.

Girish M.H, Gasti, V.D, Mastinoli, A.B, Thammaiah, N, Shantappa, T, Mulge, R. and Kerutagi, M.G. 2012. Genetic divergence studies in cluster bean genotypes (Cyamopsis tetragonoloba (L.) Taub). Karnataka Journal of Agricultural Sciences. 25(2): 245-47.

Johnson H.W, Robinson, H.F. and Comstock, R.E. 1955. Estimates of genetic and environmental variability of Soybean. Agronomy Journal. 47: 314-18.

Kastoori R, Lakkireddy, P. and Reddysekhar, M. 2009. Studies on selection indices in guar (Cyamopsis tetragonoloba (L.) Taub.). Journal of Plant Science and Biotechnology. 3(1): 26-30.

Kumar V. 2016. Path analysis in cluster bean [Cyamopsis tetragonoloba (L.) Taub] genotypes for vegetable pod yield. International Journal of Applied Science and Technology. 2(1): 21-24.

Kumar V and Ram R.B. 2015. Genetic variability, Correlation and Path analysis for Yield and Yield attributing Traits in Cluster bean [Cyamopsis tetragonoloba (L.) Taub.] Genotypes. International Journal of Pure and
Applied Bioscience. 3(1): 143-49.

Lekshmanan K.D. and Abdul, V.M. 2016. Correlation and path coefficient analysis of yield and its component characters among different accessions of cluster bean [Cyamopsis tetragonoloba (L.) Taub.]. Legume Research. 1: 1-4.

Pathak R, Singh, S.K, Singh, M. and Henry, A. 2010. Molecular assessment of genetic diversity in cluster bean (Cyamopsis tetragonoloba) genotypes. Journal of Genetics. 89(2): 243-46.

Patil D.V. 2014. Genetic variability and sowing dates effect of cluster bean (Cyamopsis tetragonoloba (L.) Taub.) genotypes in semi arid region of Maharashtra, India. Plant Archives. 14(1): 1-6.

Pawan kumar, Garg D.K and Babu Lal Jat 2017. Correlation coefficient and Path coefficient analysis for seed yield and its component traits in cluster bean [Cyamopsis tetragonoloba (L.) Taub.] Genotypes. International Journal of chemical studies. 5(4): 920-922.

Rai S.P. and Dharmatti, P.R. 2014. Correlation and path analysis for cluster bean vegetable pod yield. The Bioscan. 9(2): 811-14.

Vir O and Singh, A.K. 2015. Variability and correlation analysis in the germplasm of cluster bean [Cyamopsis tetragonoloba (L.) Taub.] . In hyper hot arid climate of Western India. Legume Research. 38(1): $37-42$.

\section{How to cite this article:}

Yeswanth Mahidar Gowd, T., P. Syam Sundar Reddy, B. Tanuja Priya, Y. Deepthi Kiran and Ramanjaneya Reddy, A. 2020. Correlation and Path Coefficient Analysis for Yield and Yield Attributes in Cluster Bean [Cyamopsis tetragonoloba (L.) Taub.] Genotypes. Int.J.Curr.Microbiol.App.Sci. 9(09): 155-164. doi: https://doi.org/10.20546/ijcmas.2020.909.019 